\title{
尿路結石症に掠けるクエン酸代謝の研究
}

1.クエン酸リアーゼを用いた尿中クェン酸の測定

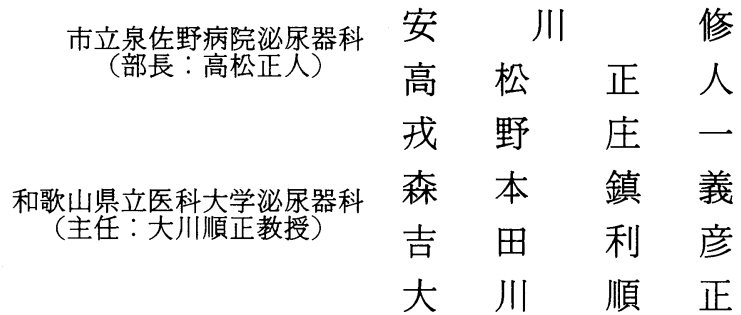

\section{STUDIES ON CITRATE METABOLISM IN UROLITHIASIS}

1. An Enzymatic Determination of Urinary Citrate with Citrate Lyase

Shu Yasukawa and Masato Takamatsu

Department of Urology, Izumisano Municipal Hospital

(Chief: M. Takamatsu)

Shoichi Ebisuno, Shigeyoshi Morimoto, Toshihiko Yoshida and Tadashi Ohkawa

Department of Urology, Wakayama Medical College

(Director: Prof. T. Ohkawa)

A method for enzymatic determination of urinary citrate using citrate lyase is described. The optimum $\mathrm{pH}$ is 7.2 and the addition of zinc ion is found to activate the reaction, but the influence of $\mathrm{pH}$ and zinc ion on the reaction velocity is reduced in proportion to increase of citrate lyase. The effect of the Tris $\mathrm{HCl}$ buffer concentration on reaction velocity is also studied, and high concentrations of the Tris $\mathrm{HCl}$ buffer are found to inhibit the reaction.

The recovery rates of citrate added to urine ranged from $98.5 \%$ to $103 \%$ and the coefficient of variation of triplicate assay is $3.1 \%$.

The urinary citrate excretion in healthy volunteers are $397 \pm 159$ and $474 \pm 209 \mathrm{mg} / \mathrm{day}$ (mean $\pm \mathrm{SD}$ ) for 66 males and 23 females, respectively.

Since this method is highly precise and convenient, it may be readily adopted as a routine clinical examination.

要旨：クェン酸リアーゼ（以下 CL）を用いた尿中クェン酸測定法につき検討した。本反応の原理は，ク エン酸がCLによりオキザロ酢酸に変換され，さらにオキザロ酢酸がリンゴ酸脱水素酵素と NADH の 存在下にリンゴ酸に変換されるときに消費される NADH の量を $340 \mathrm{~nm}$ で比色測定するというものであ る，本測定法に影響を与えると思われる諸因子につき検討したところ，Tris $\mathrm{HCl}$ buffer の $\mathrm{pH}$ は7.2付 近が最適と思われ，亜鉛イオンの添加は反応を促進することが確認されたが, $\mathrm{pH}$ や亜鉛イオンの影響は CL の量が増加してゆくにつれて生じにくくなった。 また Tris $\mathrm{HCl}$ buffer の濃度は $0.1 \mathrm{M}$ 付近で良好な 反応が得られ，高濃度の buffer は反応を阻害するようであった。

本法に括けるクェン酸の添加回収率は98.5 103\%, triplicate assay での変動係数は平均 $3.1 \%$ と信頼 に足り得るものであった。本法によって測定した健常人の 24 時間尿中クェン酸排泄量は男子 $397 \pm 159$ $\mathrm{mg} /$ day $(\mathrm{n}=66)$, 及び女子 $474 \pm 209 \mathrm{mg} /$ day $(\mathrm{n}=23)$ であった.

本測定法は前述した正確さに加光操作がきわめて簡便であり，日常検査として活用できるすぐれた方 法であると思われた。 


\section{緒言}

尿路結石患者では健常人に比して尿中クェン酸排泄 量が低い傾向にあることが比較的古くから知られてお

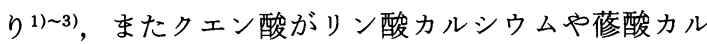
シウムの形成を阻害するという報告もなされてお り），尿路結石の成因やその再発防止に関してクェン 酸代謝の検討はきわめて重要であると考兄られる。し かしながらクエン酸の測定法が複雑かつ困難であった ため尿路結石関連物質のなかではこれまでにルーチン には測定検討されていなかったのが現状である。1966 年 Moellering \& (Gruber ${ }^{5}$ がクェン酸リアーゼ（以下 CL)を用いたクェン酸測定法を記載し，つづいてCostello \& O'Neill ${ }^{6}$, Welshman \& McCambridge ${ }^{7)}$, さら に Nielsen's)などにより本酵素法の尿中クェン酸測定 への応用が報告された。この方法により尿中クェン酸 の測定は非常に簡素化され，以後欧米では本法を用い た報告がなされてきているが，他方，本邦ではいまだ に一般的ではないようである。

著者らは Nielsenにより記載された方法にもとづ き，本酵素法を用いた尿中クェン酸定量を施行したの でその検討した結果を記載する。

\section{方法}

a. 原理

1. Citrate $\stackrel{\text { Citrate lyase }(\mathrm{CL})}{\longrightarrow}$ Oxaloacetate + Acetate

2. Oxaloacetate $+\mathrm{NADH}+$

$$
\mathrm{H}^{+} \stackrel{\text { Malate dehydrogenase }(\mathrm{MDH})}{\text { Malate }+\mathrm{NAD}^{+}}
$$

本測定法の原理は, 上記 1 の反応に括いて生ずるオ キザロ酷酸が 2 の反応によってリンゴ酸に変換される 時に消費される NADH の量が，基質であるクェン酸 の量と比例することを利用し $\mathrm{NADH}$ の量の変化を $340 \mathrm{~nm}$ で比色測定するものである.

b. 試薬, 酵素

試薬はすべて市販の特級規格を用いた。 また，試薬 の希釈にはすべて triplicate distilled water が用いら れた。

(1) $1 \mathrm{M}$ Tris $\mathrm{HCl}$ buffer $\mathrm{pH} 7.2$ : Tris (hydroxymethyl) aminomethane $121.14 \mathrm{~g}$ を再蒸留水に溶解 し, $5 \mathrm{~N} \mathrm{HCl}$ で $\mathrm{pH}$ 調整を括こない。その後, 再度, 再 蒸留水で $1 l$ とした。

(2) $0.13 \mathrm{M}$ Tris $\mathrm{HCl}$ buffer $\mathrm{pH} 7.2$ : 上記の $1 \mathrm{M}$ Tris $\mathrm{HCl}$ buffer $130 \mathrm{ml}$ に再蒸留水を加光 $1 l$ とした。
(3) $\mathrm{ZnSO}_{4} 0.6 \mathrm{mM}$

（4）クエン酸標準液 $2 g / l$. 作成後, 小試験管に細分 凍結保存し, 当日必要量を解凍して使用した。

(5) $\beta$-Nicotine amide-adenine dinucleotide: reduced form ( $\beta$ - $\mathrm{NADH}$; オリエンタル酵母工業, 測 定当日 $1 \mathrm{mg} / 1 \mathrm{ml}$ となるように $0.13 \mathrm{M}$ Tris $\mathrm{HCl}$ buffer で溶解する。

(6) Malate dehydrogenase (MDH 1; Boehringer Mannheim）測定当日 $0.13 \mathrm{M}$ Tris $\mathrm{HCl}$ buffer で50倍 希釈する。

(7) Citrate lyase (CL ; Boehringer Mannheim) 測定当日 $1 \mathrm{mg} / 0.02 \mathrm{ml}$ となるょうに $0.13 \mathrm{M}$ Tris $\mathrm{HCl}$ bufferで溶解する。

（8）測定当日，上記の試薬を混合し下記の混合試薬 を作成する，混合試薬；

1) $1 \mathrm{M}$ Tris $\mathrm{HCl}$ buffer $\mathrm{pH} 7.20 .05 \mathrm{ml} /$ sample

2) $0.6 \mathrm{mM} \mathrm{ZnSO}_{4} \quad 0.5 \mathrm{ml} /$ sample

3) $\beta$-NADH 溶液 $\quad 0.4 \mathrm{ml} /$ sample

4) $\mathrm{MDH}$ 溶液 $\quad 0.05 \mathrm{ml} / \mathrm{sample}$

$1.00 \mathrm{ml} / \mathrm{sample}$

$\beta$ - $\mathrm{NADH}$ は $-20^{\circ} \mathrm{C} て ゙ ，$ 混合試薬も含めた他の酵素

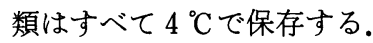

C. 比色定量法

比色計は日本分光の UVIDEC70型を用い $340 \mathrm{~nm}$ の 波長にて $\mathrm{NADH}$ 量の変化の比色定量を和こなった。

d. 測定法

標準液または尿 $0.1 \mathrm{ml}$ に0.13M Tris $\mathrm{HCl}$ buffer 1.9 $\mathrm{ml}$ を加光,さらに上記の混合試薬 $1.0 \mathrm{ml}$ を加兄擋汼, 約 5 分間静置し $340 \mathrm{~nm}$ で水に対する反応開始前の吸 光度 $\mathrm{E}_{1}$ を測定し, 次に CL 溶液 $0.02 \mathrm{ml}(1 \mathrm{mg})$ を加兄 擋找し約 10 分間放置後反応完了.後の吸光度 $\mathrm{E}_{2}$ を測定, これょり吸光度変化 $\Delta \mathrm{E}\left(\mathrm{E}_{1}-\mathrm{E}_{2}\right)$ を求める. 盲検とし て蒸留水 $0.1 \mathrm{ml}$ を試料のかわりに入れたもので同様の 操作を拈こない $\Delta \mathrm{E}^{\prime}\left(\mathrm{E}_{1}{ }^{\prime}-\mathrm{E}_{2}{ }^{\prime}\right)$ を求めると $\Delta \mathrm{E}-\Delta \mathrm{E}^{\prime}$ が $\mathrm{NADH}$ の变化量をあらわすことになる。

\section{結果}

（1）本測定法の反応に影響を及ぼすと思われる各因 子についての検討

a. 反応 $\mathrm{pH}$ と $\mathrm{CL}$ の量

Fig. 1は各反応 $\mathrm{pH}$ について吸光度の変化を経時的 に追跡したものであるが，pH 6.5 7.2付近が良好な 反応を示すことがわかる。しかし下図にみられるよう に2mg/sample の CLを用いればいずれも反応はすみ 
やかに完了し $\mathrm{pH}$ の影響は無視し得るようである．著 者らは, CL が極めて高価である点も含め， 1 検体あた り $1 \mathrm{mg}$ の CLを用い, 反応が良好な $\mathrm{pH}$ 域のうち $\mathrm{NADH}$ 溶液が比較的安定と思われる $\mathrm{pH} 7.2$ の Tris HCL bufferを用いて測定を扣こならことにした。

b. Tris $\mathrm{HCl}$ buffer $の$ 濃度

Fig. 2は Tris $\mathrm{HCl}$ buffer の各濃度に拈ける反応に つき検討した結果を示したものである，buffer の濃度 が上昇するにつれて反応が悪くなる傾向がうかがえた が，本反応条件下では $0.1 \mathrm{M}$ 以下では反応速度に有意 な差をみとめなかったので, 著者らは最終濃度約 $0.1 \mathrm{M}$ で測定を扣こならことにしている。

c. 亜鉛イオン

酵素活性化剤としての亜鉛イオンの必要性につき検 討したところ，比較的大量の CLを用いれば Fig. 3右 図に示すごとく両群の差は有意ではなくなるが，CL 量を減量してゆくと明らかに亜鉛イオン添加群でその 反応が良好となったため, 著者らは最終濃度約 $0.1 \mathrm{mM}$ となるように $\mathrm{ZnSO}_{4}$ を添加している。

Fig. 1 Influence of variations in $\mathrm{pH}$ on reaction at varying concentration on citrate lyase. Reaction condition : NADH $0.4 \mathrm{mg}, \mathrm{MDH} 0.005 \mathrm{mg}$, citrate $800 \mathrm{mg} / l, \mathrm{ZnSO}_{4}$ final concentration $0.1 \mathrm{mM}$, Tris buffer final concentration $0.1 \mathrm{M}$, cuvette volume $3.02 \mathrm{ml}$.
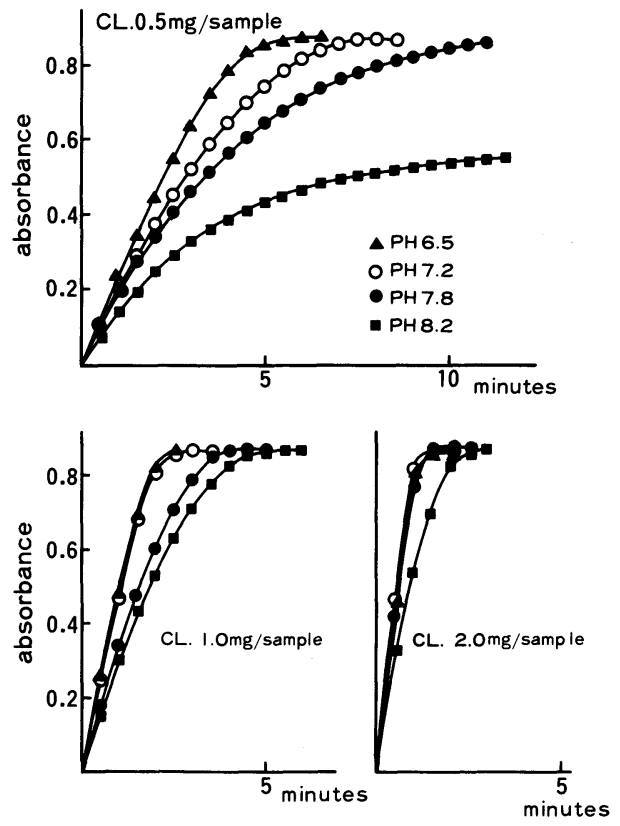

（2）クエン酸の標準曲線

以上の条件下に $40 \mathrm{mg} / l$ より $800 \mathrm{mg} / l$ までのクェン 酸標準液の検量線を求めると Fig. 4 示すごとく極 めて良好な直線関係が得られた。

Fig. 2 Influence of the Tris buffer concentration on reaction.

Reaction condition: $\mathrm{pH} 7.2, \mathrm{CL}$ lmg. Otherwise as in Fig. 1

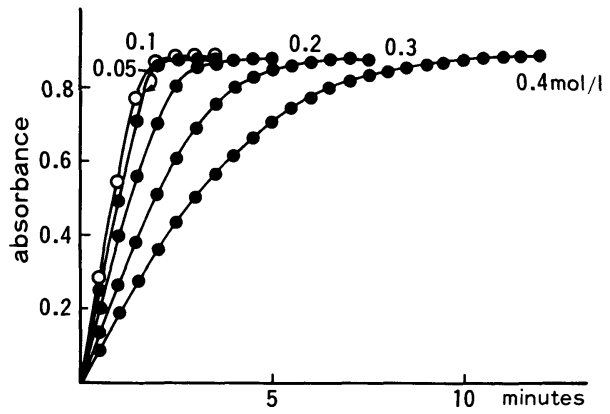

Fig. 3 Effect of the zinc ion on the reaction. Reaction condition: $\mathrm{pH} 7.2$, NADH $0.4 \mathrm{mg}, \mathrm{MDH}$ $0.005 \mathrm{mg}$, citrate $800 \mathrm{mg} / l$, CL $1 \mathrm{mg}$, Tris buffer final concentration $0.1 \mathrm{M}$, cuvette volume $3.02 \mathrm{ml}$.
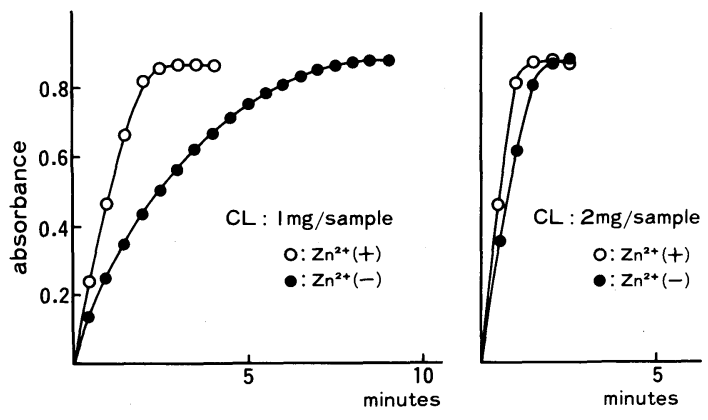

Fig. 4 Standard curve for urinary citrate.

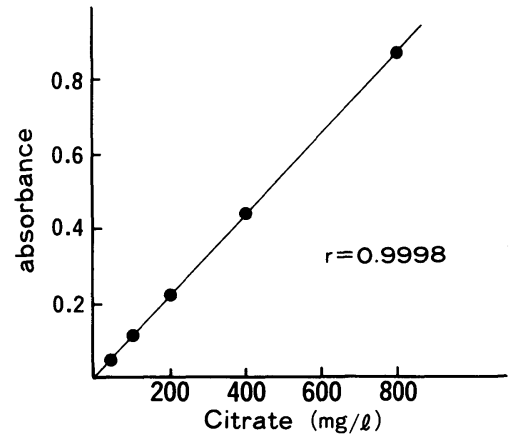


（3）測定値の再現性

10例の検体を各々 3 回測定し, その測定値, 平均値, および変動係数をTable 1に示した。変動係数は $0.3 \sim 9.5 \%$, 平均3.1\%で，これは満足できるもので あった。

(4) 既知量添加時のクエン酸回収率

Table 2は尿に各々 $50 \mathrm{mg}, 100 \mathrm{mg}$ ，および $200 \mathrm{mg} / l$ のクエン酸を添加し，それぞれの回収率を検討した結 果を示したものである. その結果, 各濃度に拈いて 98〜 103\%と極めて良好な回収率が得られた。

（5）健常人の尿中クエン酸排泄量

本測定法を用い健常人男子 66 名，女子 23 名の尿中ク エン酸排泄量を測定したところ，男子 $397 \pm 159 \mathrm{mg} /$ day, 女子 $474 \pm 209 \mathrm{mg} /$ day となり，女子の方が高値を 示したが統計上有意な差はみとめなかった。

(6) クエン酸保存の検討

クエン酸標準液 $(2 \mathrm{~g} / l)$ を作成後，これを分割凍結 保存し, 測定当日このうち 1 つを解凍し26週にわたり 追跡を抏こなったが，凍結保存による測定值の有意な

Table 1 Reproducibility of triplicate determination of urinary citrate.

\begin{tabular}{|c|c|c|c|c|c|}
\hline \multirow[b]{2}{*}{ Subject } & \multicolumn{3}{|c|}{$\begin{array}{c}\text { Citrate concentration } \\
(\mathrm{mg} / \ell)\end{array}$} & \multirow[b]{2}{*}{ Mean \pm S.D. } & \multirow{2}{*}{$\begin{array}{l}\text { Coefficient of } \\
\text { variation } \\
(\%)\end{array}$} \\
\hline & 1 & $\begin{array}{l}(\mathrm{mg} / \mathrm{l}) \\
2\end{array}$ & 3 & & \\
\hline 1 & 197 & 190 & 189 & $192.0 \pm 4.4$ & 2.3 \\
\hline 2 & 893 & 890 & 896 & $893.0 \pm 3.0$ & 0.3 \\
\hline 3 & 310 & 308 & 305 & $307.7 \pm 2.5$ & 0.8 \\
\hline 4 & 74 & 69 & 69 & $70.7 \pm 2.9$ & 4.1 \\
\hline 5 & 109 & 107 & 101 & $105.7 \pm 4.2$ & 3.9 \\
\hline 6 & 217 & 206 & 205 & $209.3 \pm 6.7$ & 3.2 \\
\hline 7 & 451 & 454 & 456 & $453.7 \pm 2.5$ & 0.6 \\
\hline 8 & 431 & 420 & 417 & $422.7 \pm 7.4$ & 1.7 \\
\hline 9 & 252 & 232 & 247 & $243.7 \pm 10.4$ & 4.3 \\
\hline 10 & 133 & 110 & 124 & $122.3 \pm 11.6$ & $\begin{array}{c}9.5 \\
(3.1 \pm 2.7)\end{array}$ \\
\hline
\end{tabular}

Table 2 Recovery of citrate added to urine.

\begin{tabular}{|c|c|c|c|c|}
\hline \multirow{2}{*}{$\begin{array}{l}\text { before addition } \\
(\mathrm{mg} / \mathrm{l})\end{array}$} & \multirow{2}{*}{$\begin{array}{c}\text { Citrate added } \\
(\mathrm{mg} / \mathrm{l})\end{array}$} & \multirow{2}{*}{$\begin{array}{l}\text { after addition } \\
(\mathrm{mg} / \mathrm{l})\end{array}$} & \multicolumn{2}{|c|}{ Recovery } \\
\hline & & & $(\mathrm{mg} / \mathrm{l})$ & $\%$ \\
\hline 95 & 50 & 143 & 48 & 96 \\
\hline 115 & 50 & 170 & 55 & 110 \\
\hline 103 & 50 & 156 & 53 & 106 \\
\hline \multirow[t]{2}{*}{319} & 50 & 369 & 50 & 100 \\
\hline & & & $51.5 \pm 3.1$ & $103 \pm 6.2$ \\
\hline 95 & 100 & 189 & 94 & 94 \\
\hline 115 & 100 & 225 & 110 & 110 \\
\hline 103 & 100 & 201 & 98 & 98 \\
\hline \multirow[t]{2}{*}{319} & 100 & 411 & 92 & 92 \\
\hline & & & $98.5 \pm 8.1$ & $98.5 \pm 8.1$ \\
\hline 95 & 200 & 293 & 198 & 99 \\
\hline 115 & 200 & 325 & 210 & 105 \\
\hline 103 & 200 & 302 & 199 & 99.5 \\
\hline \multirow[t]{2}{*}{105} & 200 & 299 & 194 & 97 \\
\hline & & & $200.3 \pm 6.8$ & $100.1 \pm 3.4$ \\
\hline
\end{tabular}

Table 3 Urinary excretion of citrate ( $\mathrm{mg} /$ day) in normal subjects.

\begin{tabular}{|c|c|c|c|}
\hline Authors & Male & Female & Method \\
\hline Hodgkinson $(1962)^{2)}$ & $556 \pm 199$ & $716 \pm 223$ & pentabromoacetone \\
\hline Elliot \& Ribeiro $(1972)^{3)}$ & $528 \pm 282$ & $706 \pm 377$ & pentabromoacetone \\
\hline Welshman \& McGeown $(1976)^{19)}$ & $370 \pm 172$ & $552 \pm 272$ & $\mathrm{CL}$ \\
\hline Bach et al. $(1981)^{20)}$ & \multicolumn{2}{|c|}{524} & $\mathrm{CL}$ \\
\hline Rudman et al $(1982)^{21)}$ & \multicolumn{2}{|l|}{$481 \pm 115$} & $\mathrm{CL}$ \\
\hline Schwille et al. $(1982)^{18)}$ & 463 & 596 & $\mathrm{CL}$ \\
\hline Nicar, et al. (1983) ${ }^{22)}$ & \multicolumn{2}{|c|}{$643 \pm 236$} & $\mathrm{CL}$ \\
\hline - & \multirow{2}{*}{\multicolumn{2}{|c|}{$306 \pm 81$}} & \\
\hline 松尾光婎 $(1966)^{23)}$ & & & pentabromoacetone \\
\hline 武本征人 $(1978)^{24)}$ & \multicolumn{2}{|c|}{$261 \pm 133^{*}$} & Hori's method \\
\hline 井口正典 他 (1981) 25) & & 309* & Hori's method \\
\hline Present study (1984) & $397 \pm 159$ & $474 \pm 209$ & $\mathrm{CL}$ \\
\hline
\end{tabular}

変化はみとめなかった。 また無処理の尿を, 室温, $4{ }^{\circ} \mathrm{C},-20^{\circ} \mathrm{C}$ の 3 群にわけて保存し 4 週間の追跡を招 こなったが，室温保存群で測定值の减少がみとめられ たが他の 2 群では有意な差はみとめられなかった (Fig. 5).

\section{考按}

クェン酸はTCA cycle の一員でありその代謝を知

Fig. 5 Influence of preserving condition of urine specimens on urinary citrate concentration. 3 urine samples were stored at different conditions for 4 weeks. No significant change of citrate concentration was found at $4{ }^{\circ} \mathrm{C}$ or $-20^{\circ} \mathrm{C}$.
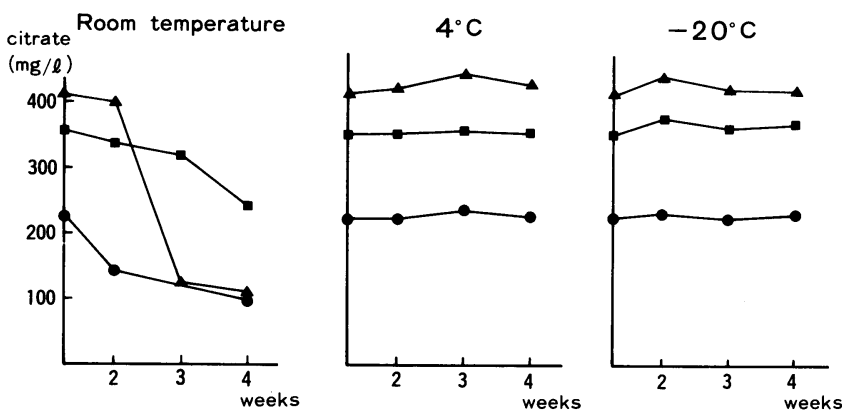
ることは有機酸代謝を知るらえで興味深く，したがっ て体液や組織中のクエン酸濃度を測定する試みは古く からなされていた。1929年，微量のクエン酸を測定す る試みとして Thunberg9)により提唱された方法は胡 瓜の種子から抽出されたクエン酸脱水素酵素を用いる 方法であった。しかしこの方法は，酵素抽出から始ま る手技の繁雑さに加光，且つその正確さにも問題があ り広く普及するには至らなかった。比較的最近まで用 いられたのはクェン酸を pentablomoacetone へと酸 化しこれを heptane や petroleum etherにて抽出後, thiourea-borax や sodium sulfideなどで発色させる といら 3 つの過程からなる方法で, これはその回収率 や再現性などから満足すべきものとされ諸家によりこ の方法で体液や組織内のクエン酸の測定が試みられて

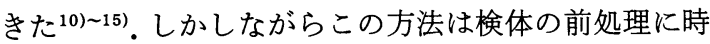
間がかかり，尿中測定についてい党ば，比較的熟練し たものでも 1 日 30 検体程度の測定を行なえるに過ざな いものであった。本邦では1974年 Hori ら ${ }^{16)}$ がクェン 酸とo-aminothiophenol 加熱するとこにより蛍光 物質が形成されることを利用した測定法を報告した が，これについてもその操作が複雑で検体の前処理に 比較的長時間を要し，前述の方法の問題点を解消した とはいえなかった。最近, Vasilikiotis ら ${ }^{17}$ により発表 された indirect kinetic method も操作には熟練を要 し，大量の検体を測定するには不向きであると思われ る.

一方，CLを用いてクエン酸を測定しようという試 みは1960年代初めに記載されているが，これが測定法 として確立されたのは1966年 Moellering \& Gruber の方法をもって嚆矢とするようである，彼らは本法を 用いて血清中や組織中のクェン酸濃度を測定した結果 を報告し，本法がきわめて微量のクエン酸を正確に測 定でき, 加えて本反応は他の TCA cycle の構成物質に よっても反応速度や正確さに影響をうけず, 感受性, 特異性ともにすぐれた方法であることを提唱した。本 法の特異性については後に Costello \& O'Neill によっ て確認され，さらにWelshman \& McCambridge は尿 に対する添加回収率もきわめてすぐれたものであるこ とを報告した。

また, Nielsen は本反応に影響を及ぼす種々の因子, すなわち buffer の $\mathrm{pH}$ や濃度, カルシウムイオンや亜 鉛イオンなどの 2 価の陽イオン, LDH の必要性など につき比較検討したが，今回著者らは諸家により比較 的一定していないbufferの $\mathrm{pH}$ と濃度, 亜鉛イオンの
必要性について検討を加えたものである. buffer の $\mathrm{pH}$ は7.6とするもの ${ }^{57)}$ と, 8.2 至適 $\mathrm{pH}$ とするも $9^{6 / 8)}$ に大別できるが，今回著者らの検討では上述した いずれの $\mathrm{pH}$ よりもやや酸性側に良好な反応を示す部 位がみとめられ，pH 8.0を超えてアルカリ域へ入ると むしろ急激に反応速度が低下する傾向さえみとめられ た. CL の至適 $\mathrm{pH}$ は諸家により若干の相違はあるが $\mathrm{pH} 7.8 \sim 8.5^{6(8) 18)}$ と $\mathrm{pH} 8.0$ 付近のアルカリ側にある ことでは一致しており，今回なぜ $\mathrm{pH} 6.5 \sim 7.2$ の付近 の反応がより良好であったかの詳細は不明であるが， あるいは $\mathrm{MDH}$ の至適 $\mathrm{pH}$ が7.4であることが影響を 及ぼしているのかもしれない.今回の検討では $\mathrm{pH} 6.5$ から7.2の間では有意な反応速度の差はみとめなかっ たが，酸性域では $\mathrm{NADH}$ 溶液がきわめて不安定にな る可能性があるため buffer の $\mathrm{pH}$ は7.2としたもので ある、な拉，本反応条件に拈いては尿は bufferなどで 約30倍に希釈されるため, 反応終了時の $\mathrm{pH}$ は尿の $\mathrm{pH}$ に全く影響をらけないことが確認されている。 buffer の濃度は Triethanolamine を用いているもの は最終濃度約 $65 \mathrm{mM}$ で反応をおこなっており ${ }^{577)}$, Tris を用いている Costello \& O’Neill は約 $20 \mathrm{mM}$, Nielsen は $100 \mathrm{mM}$ と若干の差がみとめられるが，前者はクエ ン酸を $10^{-5} \mathrm{M}$ 以下と極めて低濃度で測定しており，こ れを除くと概ね 50 ～100 $\mathrm{mM}$ の濃度が適するよらであ る. Nielsen は buffer の濃度を上昇させると CL の活 性が低下すると述べているが，今回の検討でも同様の 結果が得られた。この理由は明らかにされていないが イオン強度などが何らかの影響を与えているのかもし れない。

酵素活性化剂としての亜鉛イオンについても，必要

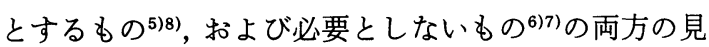
解が出されているが，基質量に対して酵素量が比較的 多量であるときには本反応はすみやかに完了するため 両群の間に差は生じにくく，酵素量の減量とともに明 らかな差があらわれ，この際亜鉛イオン添加群が良好 な反応を示すようである。また，亜鉛イオン濃度につ いても検討が必要であるが，今回著者らは諸家より報 告されている0.1mM を用いた。

本法の測定限界は NADH 量に依っているが，尿中 クェン酸濃度は概ね $1,000 \mathrm{mg} / l$ 以下であることを考 学ると 1 検体あたり 4 5 mg を用いれば充分であると 思われる。

本法を用いて健常人の尿中クェン酸排泄量を測定し た結果は, 男子 $397 \mathrm{mg} / \mathrm{day}$, 女子 $474 \mathrm{mg} /$ day であり欧 
米の報告とくらべると若干低い傾向がみとめられた (Table 3). 今回の検討では食事や水分の制限は何ら おこなっていないこと，また女子に関しては性周期が 考慮されていないこと, さらに蓄尿法の問題などの若 干の問題点があるもかもしれないが, 本邦の 2,3 の報 告ともあわせ考兄てみると，日本人の尿中クェン酸排 泄量は欧米人に比してやや低值ではないかと推定され るところであるが，これらについては今後さらに検討 してゆく予定である。

本測定法の最大の利点は従来のいずれの方法と比較 しても操作がきわめて簡便で短時間に多量の検体の測 定が可能という点にある。すなわち，本法は尿の前処 理を全く必要とせず, 混合試薬と溶解した CLを除け ば他の試薬は比較的長期間保存することが可能であ り, かつ 2 時間で50検体の測定が可能である。 また今 回の検討では回収率および再現性の点でも極めてすぐ れた方法であるとの結果が得られて扣り，本法は日常 臨床検查としても十分に活用され得るものと考光る.

\section{結 果}

クェン酸リアーゼ $(\mathrm{CL})$ を用いる尿中クェン酸測定 法につき検討し以下の結果を得た。

(1) Tris $\mathrm{HCl}$ buffer $9 \mathrm{pH}$ は7.2, 最終濃度 $0.1 \mathrm{M}$ で満足すべき反応が得られたが，CLを増量してゆく と $\mathrm{pH}$ による影響は生じにくくなるものと思われた。

（2）亜鉛イオンは CL 量が少量のときその反応を促 進し, 添加の必要性が認められた。

（3）本法の尿に抢ける゙クェン酸の回収率は 98 103\%であり, triplicate assay での変動係数は 0.3〜9.5\%であった。

（4）本法によって今回測定した健常人の尿中クェン 酸排泄量は男子 $397 \pm 159 \mathrm{mg} / \mathrm{day}(\mathrm{n}=66)$, 女子 $474 \pm$ $209 \mathrm{mg} /$ day $(\mathrm{n}=23)$ であった。

（5）本法は操作がきわめて簡便であるため短時間で 多量の検体の測定が可能であり，日常検査として活用 できるきわめてすぐれた方法であると思われた。

\section{文献}

1) Kissin, B. and Locks, M.O.: Urinary citrates in calcium urolithiasis. Proc. Soc. Exp. Biol. Med., 46, 216-218, 1941.

2) Hodgkinson, A.: Citric acid excretion in normal adults and in patients with renal calculus. Clin. Sci., 23, 203-212, 1962.

3) Elliot, J.S. and Ribeiro, M.E.: The urinary excretion of citric, hippuric, and lactic acid in normal adults and in patients with calcium oxalate urinary calculus disease. Invest. Urol., 10, 102-106, 1972.

4) Hallson, P.C., Rose, G.A. and Sulaiman, S.: Raising urinary citrate lowers calcium oxalate and calcium phosphate crystal formation in whole urine. Urol. Int., 38, 179-181, 1983.

5) Moellering, H. and Gruber, W.: Determination of citrate with citrate lyase. Anal. Biochem., 17, 369-376, 1966.

6) Costello, L.C. and O'Neill, J.J.: A simplified and sensitive method for citrate determination in biological samples. J. Appl. Physiol., 27, 120-122, 1969.

7) Welshman, S.G. and McCambridge, H.: The estimation of citrate in serum and urine using a citrate lyase technique. Clinica Chimica Acta, 46, 243-246, 1973.

8) Nielsen, T.T.: A method for enzymatic determination of citrate in serum and urine. Scand. J. Clin. Lab. Invest., 36, 513-519, 1976.

9) Thunberg, T.: Über das Vorkommen einer Citrico-Dehydrogenase in Gurkensamen und ihre Verwertung fülr eine hochempfindliche biologische Farbenreaktion auf Citronensäure. Biochem. Z., 206, 109-119, 1929.

10) Pucher, G.W., Sherman, C.C. and Vickery, H. B. : A method to determine small amounts of citric acid in biological material. J. Biol. Chem., 113, 235-245, 1936.

11) Natelson, S., Lugovoy, J.K. and Pincus, J.B.: Determination of micro quantities of citric acid in biological fluids. J. Biol. Chem., 170, 597 $-606,1947$.

12) Taussky, H.H. and Shorr, E.: A microcolorimeteric method for the determination of citric acid. J. Biol. Chem., 169, 103-118, 1947.

13) Ettinger, R.H., Goldbaum, L.R. and Smith, L.H. Jr.: A simplified photometric method for the determination of citric acid in biological fluids. J. Biol. Chem., 199, 531-536, 1952.

14) Beutler, E. and Yeh, M.K.Y.: A simplified method for the determination of the citric acid. J. Lab. Clin. Med., 54, 125-131, 1959.

15) Grumbaum, B.W. and Pace, N.: Microchemical urinalysis VII. Determination of citric acid in microliter quantities of urine. Microchem. J., 15, 673-676, 1970.

16) Hori, M., Kometani, T., Ueno, H. and Morimoto, H.: A new fluorometric analysis of citric acid. Biochem. Med., 11, 49-59, 1974.

17) Vasilikiotis, G.S., Papadopoulos, C., Themelis, D.G. and Sofoniou, M.C.: Indirect kinetic 
microdetermination of oxalate. citrate, and fluoride ions. Microchem. J., 28, 431-436, 1983.

18) Schwille, P.O., Scholz, D., Schwille, K., Leutschaft, R., Goldberg, I. and Siegel, A.: Citrate in urine and serum and associated variables in subgroups of urolithiasis. Results from an outpatient stone clinic. Nephron, 31, 194-202, 1982.

19) Welshman, S.G. and McGeown, M.G.: Urinary citrate excretion in stone-formers and normal controls. Brit. J. Urol., 48, 7-11, 1976.

20) Bach, D., Hesse, A. and Vahlensieck, W.: 24hour excretion and circadian rhythm of citric acid in stone-formers and normal subjects on a standard diet. Urinary Calculus, p. 117, PSG Publishing Co., Littleton, Massachusetts, 1981.

21) Rudman, D., Kunter, M.H., Redd, S.C. II., Waters, W.C. IIV., Gerron, G.G. and Bleier, J.
Hypocitraturia in calcium nephrolithiasis. J. Clin. Endo. Metab., 55, 1052-1057, 1982.

22) Nicar, M.J., Skurla, C., Sakhaee, K. and Pac, C. Y.C.: Low urinary citrate excretion in nephrolithiasis. Urology, 21, 8-14, 1983.

23）松尾光雄：尿石症の成因に関寸る研究. 第 III 編. 尿石症に拈ける尿中 Citrate 排泄の意義につい て. 泌尿紀要, 12, 869-880，1966.

24）武本征人：炭酸脱水素阻害剤によって誘発される 尿路結石症の予防に関する臨床的研究. 日泌尿会 誌，69，068-987，1978.

25）井口正典, 片岡喜代徳, 郡健二郎, 八竹 直, 栗田 孝：尿路結石の発生原因に関する検討（第 2 報）

一正常女性における性周期が尿中クェン酸打よび 電解質排泄量に及ぼす影響について一。目泌尿会 誌，72，856-864， 1981.

（1985年 2 月 25 日受付） 